Rodríguez, F., D. Escoto, T. Mejía-Ordóñez, L. Ferrufino-Acosta, S. Y. Cruz, J. E. Duchamp, and J. L. Larkin. 2019. Influence of microhabitat on Honduran Emerald (Amazilia luciae) abundance in tropical dry forest remnants. Avian Conservation and Ecology 14(1):3. https://doi.org/10.5751/ ACE-01321-140103

Copyright $(0) 2019$ by the author(s). Published here under license by the Resilience Alliance.

Research Paper

\title{
Influence of microhabitat on Honduran Emerald (Amazilia luciae) abundance in tropical dry forest remnants
}

\author{
Fabiola Rodríguez ${ }^{1}$, Dorian Escoto ${ }^{1}$, Thelma M. Mejía-Ordóñez ${ }^{2}$, Lilian Ferrufino-Acosta $^{2}$, Saby Y. Cruz ${ }^{2}$, Joseph E. Duchamp $^{1}$ \\ and Jeffery L. Larkin ${ }^{1,3}$ \\ ${ }^{1}$ Department of Biology, Indiana University of Pennsylvania, Indiana, Pennsylvania, USA, ${ }^{2}$ Escuela de Biología, Ciudad \\ Universitaria, Universidad Nacional Autónoma de Honduras, Tegucigalpa, Francisco Morazán, Honduras, ${ }^{3}$ American Bird \\ Conservancy, The Plains, Virginia, USA
}

\begin{abstract}
Understanding the ecology of at-risk species is the foundation for developing strategies to counteract continued population declines. The Honduran Emerald (Amazilia luciae) is an endemic hummingbird that inhabits tropical dry forest in Honduras. Remaining populations of this endangered species are restricted to habitat fragments located in landscapes dominated by agricultural activities. The conservation of this species is dependent on efforts to protect existing dry forest remnants and to restore additional areas. However, limited information exists regarding Honduran Emerald habitat use on which to base management decisions. We conducted a study to identify point-level habitat features that are important to Honduran Emerald abundance. In 2014-2015, we conducted avian and vegetation surveys at 174 points located within dry forest remnants. We constructed hierarchical multinomial mixture models using time-removal based point count data collected in three sampling periods. Honduran Emerald detection was influenced negatively by Julian date. Local abundance was positively correlated with shrub-sapling density and cacti structural diversity. Mean local abundance per point was $(0.39 \pm 0.2 \mathrm{SD})$ and the number of individuals estimated to have used the combined area of the survey points (48.7 ha) was 68 (CI 95\% 45-110). The shrub-sapling density and cacti structural diversity levels identified from our abundance models are characteristic to dry forest communities in this region. As such, the need for efforts to protect remaining dry forest remnants cannot be overstated. Future research should evaluate how the microhabitat features we found to be important to Honduran Emerald abundance influence fitness parameters such as survival and reproduction. Studies that examine how reciprocal effects of pollinator species declines and plant species diversity influences the long-term stability of tropical dry forest ecosystems are also warranted.
\end{abstract}

\section{Influence du micro-habitat sur l'abondance de l'Ariane de Lucy (Amazilia luciae) dans les vestiges de forêts tropicales sèches}

RÉSUMÉ. Comprendre l'écologie des espèces en péril est la base de l'élaboration de stratégies visant à contrer le déclin continu des populations. L'Ariane de Lucy (Amazilia luciae) est un colibri endémique qui vit dans la forêt tropicale sèche du Honduras. Les populations restantes de cette espèce en danger sont limitées à des fragments d'habitat situés dans des paysages dominés par des activités agricoles. La conservation de cette espèce dépend des efforts déployés pour protéger les vestiges de forêt sèche existants et pour restaurer d'autres zones. Cependant, peu d'informations sont disponibles quant à l'utilisation de l'habitat de l'Ariane de Lucy sur lesquelles fonder les décisions de gestion. Nous avons mené une étude pour identifier les caractéristiques de l'habitat au niveau ponctuel qui sont importantes pour l'abondance de l'Ariane de Lucy. En 2014-2015, nous avons effectué des relevés d'oiseaux et de végétation sur 174 points situés dans des vestiges de forêts sèches. Nous avons construit des modèles de mélanges multinomiaux hiérarchiques à l'aide des données des dénombrements ponctuels, basées sur l'élimination du temps, collectées au cours de trois périodes d'échantillonnage. La détection de l'Ariane de Lucy était négativement corrélée au jour Julien. L'abondance locale était positivement corrélée à la densité d'arbustes et à la diversité structurelle des cactus. L'abondance locale moyenne par point était de 0,39 $\pm 0,2$ DS et le nombre d'individus ayant utilisé la superficie totale des points d'étude (48,7 ha) était de 68 (IC 95\% $45-110)$. La densité d'arbustes et les niveaux de diversité structurelle des cactus identifiés à partir de nos modèles d'abondance sont caractéristiques des communautés de forêts sèches de cette région. En conséquent, on ne saurait trop insister sur la nécessité de déployer des efforts pour protéger les vestiges restants des forêts sèches. Des recherches futures devront évaluer dans quelle mesure les caractéristiques du micro-habitat que nous avons trouvées importantes pour l'abondance de l'Ariane de Lucy ont une incidence sur les paramètres de condition physique tels que la survie et la reproduction. Des études qui examineraient comment les effets réciproques du déclin des espèces pollinisatrices et de la diversité des espèces végétales influencent la stabilité à long terme des écosystèmes des forêts tropicales sèches sont également justifiée

Key Words: Agalta Valley; habitat use; hierarchical models; hummingbird 


\section{INTRODUCTION}

Effective conservation of biodiversity in landscapes impacted by human activities is aided by the degree to which biodiversity is monitored and studied in the face of habitat degradation and loss (Collen et al. 2013). Ecologists have often considered species abundance as one of the fundamental population metrics to evaluate anthropogenic influences on wildlife (Apps et al. 2004, Heikkinen et al. 2004, Marsh and Trenham 2008). For example, abundance has been used in population-specific studies to inform management and conservation issues of rare or endangered species (Nichols and Mackenzie 2004, Kéry and Royle 2016). When species abundance can be evaluated in the context of habitat structure and composition, studies can offer insight to those habitat conditions that are important for population recovery. Moreover, results from such studies have the potential to inform habitat management and other conservation efforts (Iwata et al. 2003, Heikkinen et al. 2004, Segura and Arturi 2012).

Tropical dry forests are considered a globally threatened ecosystem, with an estimated $60 \%$ of their original extent lost and the rest highly threatened by fragmentation (Sánchez-Azofeifa et al. 2013, Blackie et al. 2014). These forests may not match tropical rainforests in their high level of plant diversity, but they hold a significant amount of plant endemism and are characterized by their high floristic turnover across their distribution (Gentry 1995, Banda et al. 2016). Areas that support tropical dry forests have been historically selected by humans for settlement (GómezPompa et al. 1987, Bush et al. 1992), and today, many landscapes that support tropical dry forests remain important for human communities (Blackie et al. 2014). The area of tropical dry forest in the Agalta Valley, Honduras, has been drastically reduced over the past several decades as the valley continues to be transformed into a working landscape driven by dairy production (Banco Interamericano de Desarrollo 2009). Continued encroachment of human land uses on dry forest remnants may jeopardize the persistence of many species that specialize on this plant community.

Among the many species that have been affected by tropical dry forest loss is the Honduran Emerald, Amazilia luciae (Fig. 1), an endangered hummingbird that is endemic to tropical dry forests of Honduras (Anderson et al. 2013, BirdLife International 2016). The species is now restricted to only five locations, i.e., departments, throughout Honduras that support varying amounts of dry forest habitat (Fig. 2A; eBird 2017). The status of the Honduran Emerald in the Agalta Valley is especially tenuous because the species is predicted to become locally extinct within the next decade unless considerable conservation measures are employed (Anderson et al. 2013).

To effectively address conservation needs of the Honduran Emerald it is important to quantify population parameters, i.e., population size (Anderson et al. 2010), and to link such parameters with empirically accessed habitat conditions. Despite first being described by Lawrence (1867), little is known about Honduran Emerald ecology (Anderson et al. 2010). Most of what is known about the species is the result of anecdotal observations, descriptive accounts, contemporary expeditions, and environmental impact assessment reports (Howell and Webb 1989, Thorn et al. 2000, Anderson and Hyman 2007, Anderson et al. 2010, Espinal and Mora 2012, INGTELSIG 2013). To date, no studies have quantified the influence of point-level vegetation on Honduran
Emerald abundance. Several studies in avian ecology have previously demonstrated the utility of habitat-species abundance relationships to highlight the role of vegetation structure and composition for species conservation (Pardini et al. 2005, GómezMontes and Bayly 2010) and to assess the population status of species in a given locality (Sillett et al. 2012, Rivera-Milán et al. 2015). Therefore, blueprints exist to study how Honduran Emerald local abundance is driven by vegetation characteristics in tropical dry forest remnants. Furthermore, floristic communities that shape tropical dry forests across the Americas are considered irreplaceable with areas in need of conservation throughout the continent (Banda et al. 2016). As such, understanding the interrelationships of the species within this ecosystem will increase our knowledge of Honduran Emerald ecology and of the impact that anthropogenic threats will have on these species (Sánchez-Azofeifa et al. 2013).

Fig. 1. Honduran Emerald hummingbird (Amazilia luciae) is a species endemic to Honduras. (A) An area of dry forest dominated by shrub. (B) Honduran Emerald feeding from Aechmea bracteata in Santa Bárbara department, the western range of the species (Photo by: Mayron Mejía, 2018). (C) A Honduran Emerald hovering in its habitat in the department of Cortés (Photo by: Alex Martínez Matute, 2018).
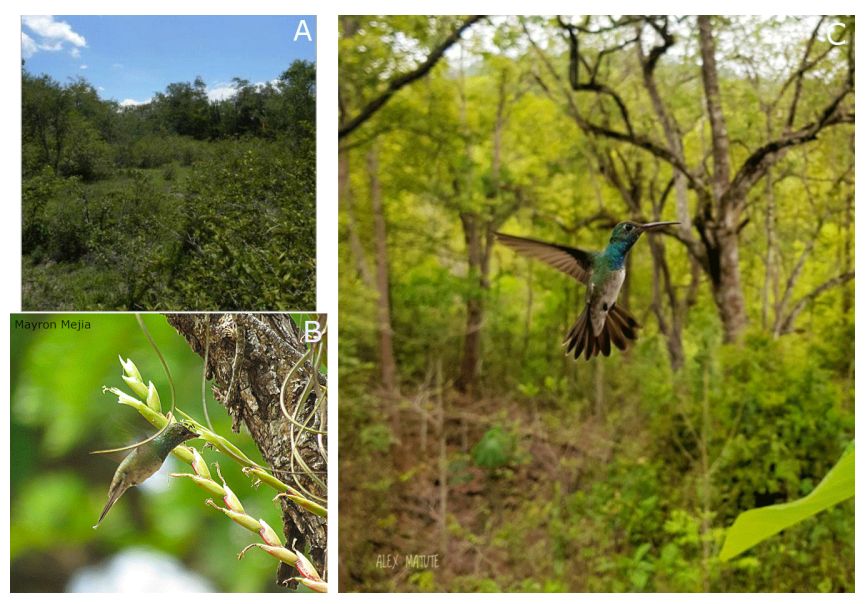

Our aim was to evaluate the relationship between Honduran Emerald abundance and microhabitat features of tropical dry forest remnants in the Agalta Valley. Our use of the term "microhabitat" is similar in context to Cahill and Matthysen (2007) or Renfrew and Ribic (2008) and refers to vegetation structure and species composition features that are quantified at the survey point level. Study objectives were to (i) determine mean detection probability and local abundance of Honduran Emerald, (ii) identify how microhabitat features influence local abundance of Honduran Emerald, and (iii) summarize the microhabitat features of dry forest remnants in which we detected Honduran Emeralds.

\section{METHODS}

\section{Study area}

During August 2014 to July 2015, we conducted surveys in 35 dry forest remnants (0.5-380 ha) within the Agalta Valley (Fig. 2B). The geographic extent of the Agalta Valley is approximately 
Fig. 2. (A) Honduran Emerald (Amazilia luciae) locations within its range in Honduras (eBird 2017). (B) Study area in the Agalta Valley with tropical dry forest remnants (NASA LP DAAC 2011; Asociación de Investigación para el Desarrollo Ecológico y Socioeconómico [ASIDE] 2014, shapefile) where Honduran Emerald surveys and vegetation sampling were conducted during 2014-2015.

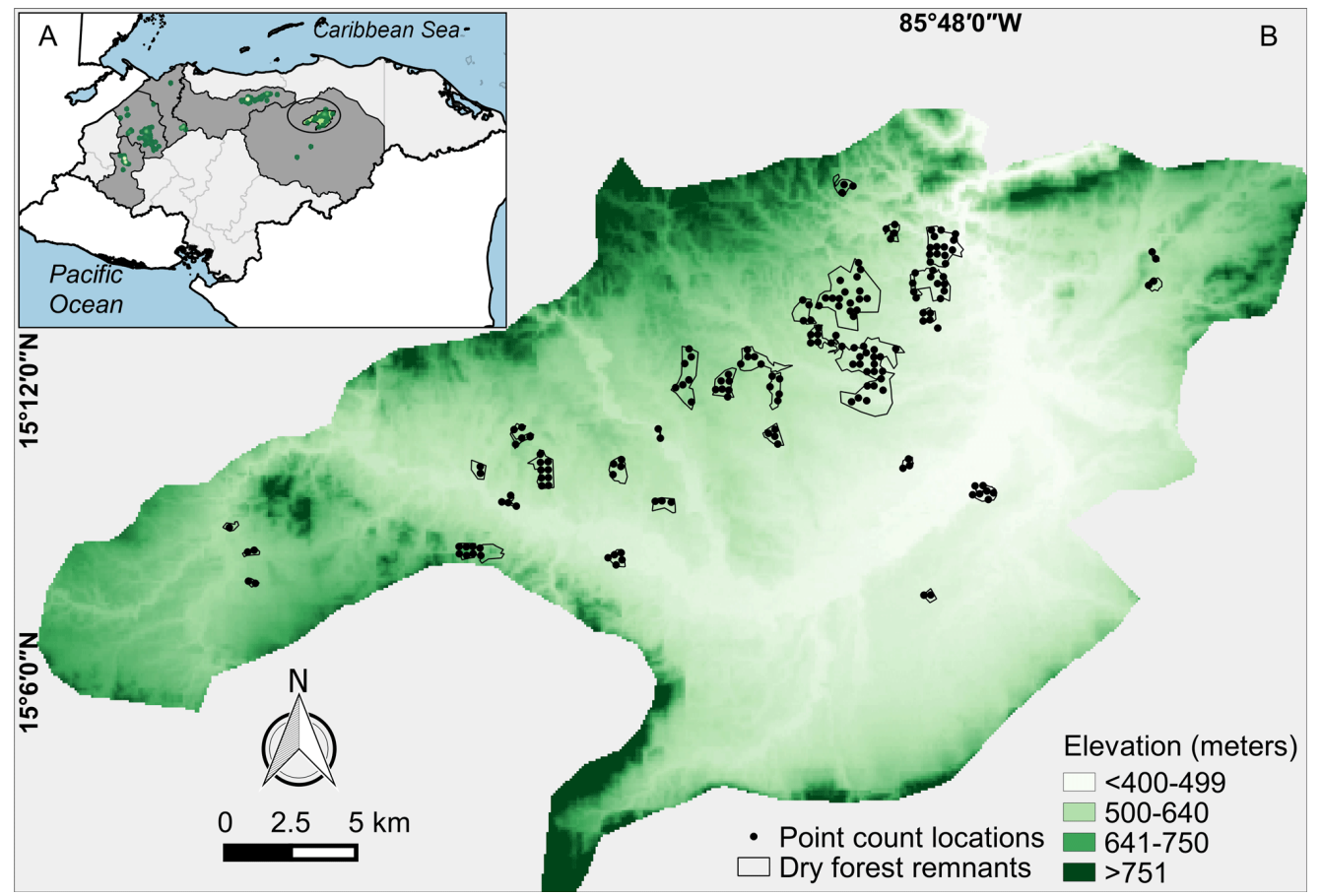

70,000 ha in which tropical dry forest communities exist as patchily distributed remnants of varying successional stages, within a landscape dominated by pasture and croplands $(\sim 77 \%$; Espinal and Mora 2012, Rodríguez et al. 2015). The 35 dry forest remnants we studied were selected based on accessibility and permission from landowners. Remnants were composed of a mosaic of dry forest vegetation and open to semiopen areas associated with cattle farming activities (Fig. 1A, 1C). Tropical dry forest of the Agalta Valley comprises open thorn or semideciduous forests, semideciduous dry forests, or shrub dominated areas, with a mean canopy height of $5.95 \pm 0.02 \mathrm{SE}$ $\mathrm{m}$, of which the majority may be considered low standing trees. In these communities, dominant plant species include Acacia picachensis (Fabaceae), Eugenia hondurensis (Myrtaceae), Casearia nitida (Salicaceae), and Erythroxylum areolatum (Erythroxylaceae). The understory strata ranges from sparse to dense and may comprise saplings and shrub species such as Solanum dasyanthum (Solanaceae), Schoepfia schreberi (Schopefiaceae), Bernardia nicaraguensis (Euphorbiaceae), and Mimosa tenuiflora (Fabaceae). Additionally, the understory strata may include nonwoody species such as Hechtia guatemalensis (Bromeliaceae), Aechmea bracteata (Bromeliaceae), and Opuntia hondurensis (Cactaceae; Ferrufino-Acosta, Cruz, MejíaOrdóñez, et al., unpublished manuscript).

\section{Avian surveys}

We used QGIS to randomly select point count survey locations within each of the 35 tropical dry forest remnants (Quantum GIS Development Team, https://qgis.org/en/site/). This resulted in the selection of 179 points that were spaced at least $300 \mathrm{~m}$ apart (Fig. 2B). Of these we only analyzed data from 174 points because of loss of habitat or access to the points within the study period. We conducted point count surveys between 0600 and $1000 \mathrm{hrs}$ on days with appropriate weather conditions, e.g., no rain (Lynch 1995). We surveyed each point during three periods throughout the year-long study (30 September-9 December; 4 March-28 April; 21 June-27 July). At the beginning of each point count survey, we allowed a 1-minute "settle period" to elapse before starting the survey (Bibby et al. 1992). Each point count consisted of a 10-minute passive listening phase in which all Honduran Emeralds seen or heard were recorded. Listening phases were organized into five 2-minute time-removal intervals (Farnsworth et al. 2002).

Surveys throughout the study period were conducted by two observers (FR and DE). These observers trained together during two days in August 2014, in one of the largest dry forest fragments and conducted trial point counts to learn the point count protocols. Subsequently, the observers conducted the first period of sampling (September-December) together to standardize their ability to record data: detections of Honduran Emeralds and recording of Honduran Emeralds in the adequate intervals. In the subsequent sampling periods (March-April and June-July), each observer worked separately to maximize the points visited per survey. For this reason in these two sampling periods, we considered observer as a potential variable in our models to account for possible differences between them in our ability to detect Honduran Emeralds. 


\section{Vegetation surveys}

We conducted vegetation surveys at each point where we had conducted avian point counts. In each plot we collected vegetation structure and plant species composition data within nested plots based on Nudds (1977), Bibby et al. (1992), Martin et al. (1997), Nassar et al. (2008), and García-Villacorta (2009). Within a 5-m radius plot we recorded (1) average shrub-sapling height (m) estimated by observers, and (2) shrub-sapling stem count including woody species in the shrub strata $<2 \mathrm{~m}$. Within a 12.6 $\mathrm{m}$ radius plot we recorded the following: (1) diameter at breast height (DBH) for woody plants $\geq 3 \mathrm{~cm} \mathrm{DBH}$; (2) tree height (m) for each woody plant $\geq 3 \mathrm{~cm} \mathrm{DBH}$ estimated by observers; (3) tree species; (4) count of trees or cacti with presence of epiphytic bromeliads; (5) number of cacti; (6) cacti height (m) for each individual estimated by observer; (7) count of woody stems $<3$ $\mathrm{cm} \mathrm{DBH}$; and (8) average horizontal vegetation density measured using a 2-m tall density board consisting of a cloth scroll comprising twenty $20 \times 20 \mathrm{~cm}$ grid cells. To quantify this measurement an observer stood at plot center while another observer held the density board $10 \mathrm{~m}$ away in each of the four cardinal directions. The observer at plot center recorded the number of grid cells covered $\geq 50 \%$ by vegetation. To minimize errors in estimation, all vegetation measurements were collected by the same observers during all surveys. Once vegetation measurements were completed, we collected representative plant samples throughout each plot, preferably from individuals with fruit or flowers. Plants were pressed, transported to the Universidad Nacional Autónoma de Honduras (UNAH), to be identified to species and deposited at the Herbarium Cyril Hardy Nelson Sutherland (TEFH) in UNAH. We deposited a duplicate of the samples at the A. G. Shields Herbarium in Indiana University of Pennsylvania.

\section{Statistical analysis}

First, we summarized the vegetation metrics to generate 15 variables (Table 1). These variables reflect the structure and taxonomic composition of microhabitat features of each survey location (Table 1). Prior to analysis, we standardized all microhabitat features to have a mean zero and standard deviation of one. Additionally, we evaluated for correlations using the Pearson coefficient $(r \geq 0.75$ or $\leq-0.75)$. Only two covariates, woody species richness and Shannon Diversity, were highly correlated (Pearson coefficient $=0.85$ ), and we chose to exclude the latter from our analyses. Ultimately, we included 14 variables (Table 1) in the hierarchical models to relate Honduran Emerald abundance to microhabitat features.

We analyzed data from our three Honduran Emerald survey periods separately to limit our inferences to time periods when the population was sampled consistently. We assume that within each survey period, populations are likely to be closed. However, because of the mobility of our study species we interpreted our abundance values as the number of individuals that potentially use the sampling points at a given time, as opposed to absolute number of individuals (Chandler et al. 2011). We screened the raw counts of Honduran Emeralds and included detections that were $\leq 30$ meters from the observer. Observations beyond this distance were sparse and may not have captured the microhabitat features that we measured. Honduran Emerald counts within each sampling period were tested for spatial autocorrelation using Moran's I test within the "ape" package in R (Paradis and Schliep 2018).

We analyzed the local abundance patterns with the "unmarked" package in program $\mathrm{R}$ for model building (Fiske and Chandler 2011, R Core Team 2017). We followed the multinomial Nmixture modeling framework using the Poisson mixture, incorporating a time-removal specification with the information from the count time-intervals (Farnsworth et al. 2002, Royle $2004 a$ ). We fit models in a two phase process. First, we fitted models that only considered the detection probability covariates of Julian date, observer, and vegetation density and kept abundance constant. We used the highest-ranking model from this phase for posterior modeling of abundance. Then, we fit models with the top detection covariate of the previous phase and the vegetation variables that may influence Honduran Emerald abundance (Table 1). To avoid overparameterization in the models, because of low number of detections, we fit single variable models and single variable with quadratic terms for each of the 14 variables. We ranked the models based on the Akaike Information Criteria corrected for small sample sizes (AICc) using the package "AICc modavg" (Hurvich and Tsai 1989, Mazerolle 2017). The top model was selected for the estimation of mean abundance per point and local abundance. We evaluated the confidence intervals at the $85 \%$ level because we consider them appropriate for exploring the informative value of our proposed variables (Arnold 2010). Additionally, we conducted a goodness of fit test with three fit statistics (Chi-square, FreeTukey, and sums of squares) and 10,000 repetitions following Kéry and Royle (2016). Models up to $\triangle \mathrm{AICc}=7$ were evaluated to identify variables that could be considered in future studies, albeit these are less likely to influence abundance based on our data (Burnham and Anderson 2002). We present the results of the models fit in phase two and the null model in a table.

Finally, we summarize the vegetation variables of used and unused point count locations. For all vegetation variables, we conducted a two-sample t-test and applied a Holm's correction factor to account for multiple testing (Holm 1979). We present test results for both corrected and uncorrected comparisons. The corrected comparisons were used to consider the effect of the differences between used and unused points, whereas the uncorrected comparisons were used to identify microhabitat features that warrant inclusion in future Honduran Emerald studies.

\section{RESULTS}

We detected Honduran Emeralds at 86 of 174 point count locations in tropical dry forest remnants during all three survey periods combined. In period one (September-December), we recorded 46 Honduran Emeralds at 41 of $174(24 \%)$ survey points. During period two (March-April), we recorded 67 Honduran Emeralds at 57 of 174 (33\%) survey points, and during period three (June-July), 30 Honduran Emeralds at 28 of $174(16 \%)$ survey points. A total of five detections $>30 \mathrm{~m}$ were not included in the analyses (four and one for the first and second sampling periods, respectively). We did not find evidence for spatial autocorrelation for Honduran Emerald counts for all sampling periods (Appendix 1). 
Avian Conservation and Ecology 14(1): 3

http://www.ace-eco.org/vol14/iss1/art3/

Table 1. Structure and composition microhabitat features of the Agalta Valley's tropical dry forest remnants used in the analysis of Honduran Emerald (Amazilia luciae) local abundance.

\begin{tabular}{l}
\hline Microhabitat feature \\
\hline Holdridge Complexity Index (HCI) \\
Density of woody stems $<3 \mathrm{~cm} \mathrm{DBH}$ \\
Standardized Pretzsch index (Cacti structural \\
diversity)
\end{tabular}
diversity)

Proportion of Opuntia hondurensis cacti

Proportion of Pilosocereus leucocephalus cacti

Shrub-sapling density (no. stems/ha)

Vegetation density $(\%)$

Importance Value (IVI) Acacia picachensis

Importance Value (IVI) Eugenia hondurensis

Importance Value (IVI) Erythroxylum areolatum

Importance Value (IVI) Casearia nitida

Epiphyte tree count

Patch size

Shannon Diversity Index

Woody plant species richness

Description Rationale

Incorporates height, stand basal area, density of Quantifies the structural physiognomy and stems $\geq 3$ DBH (each tree stem contributing complexity of Agalta's dry forest remnants and its individually), wood plant species richness (Holdridge et al. 1971).

value represents succession gradients (EspíritoSanto et al. 2014).

Density per ha of tree and sapling stems under $3 \mathrm{~cm}$ May reflect cover for Honduran Emerald against DBH. predators.

This index combines height and presence of species This standardized species profile index (Arel) was to reflect the contribution of cacti species richness in each of three levels of a vertical distribution (Pretzsch 2009). Three levels were determined based adapted to cacti. Three levels were selected based on applications in other vegetation ecology studies on the raw individual height distribution for cacti: Cacti are one of the characteristic families of 0-7.5 m (level III or lower stratum), 7.5-12 m (level tropical dry forest floristic composition (Gentry II or medium stratum), and 12-15 m (level III or 1995). high stratum).

Proportion of individuals of Opuntia hondurensis relative to all cacti individuals present in the plot.

Proportion of individuals of Pilosocereus leucocephalus relative to all cacti individuals present in the plot.

Shrub density is represented by all woody plants under two meters that have solely a shrub growth habit or may have both shrub and tree growth habit.

Percentage of horizontal cover present within two $\mathrm{m}$ of height.

Quantified at the plot level with the two available parameters of height and basal area (Mostacedo and Fredericksen 2000) for Acacia picachensis one of the highest IVI values overall for Agalta as composition microhabitat features. Quantified at the plot level with the two available parameters of height and basal area (Mostacedo and Fredericksen 2000) for Eugenia hondurensis one of the highest IVI values overall for Agalta as composition microhabitat features. Quantified at the plot level with the two available parameters of height and basal area (Mostacedo and Fredericksen 2000) for Erythroxylum areolatum one of the highest IVI values overall for Agalta as composition microhabitat features.

Quantified at the plot level with the two available parameters of height and basal area (Mostacedo and Fredericksen 2000) for Casearia nitida one of the highest IVI values overall for Agalta as composition microhabitat features.

Count per plot of the individual woody plants greater than three $\mathrm{cm}$ DBH with presence of at least one epiphytic bromeliad.

Area in ha of the polygon representing the study site that contains the point count location.

Shannon Diversity Index presented in effective species units. Effective species units (D) is calculated by taking the base of the natural logarithm of the Shannon Diversity Index. D = eH'. Species richness of all individuals $\geq$ three $\mathrm{cm}$ DBH. Indicates plant species richness.
Indicates the availability of one of the Honduran Emerald common food sources in the height stratum where most individuals of this cactus species were concentrated $(0-7.5 \mathrm{~m})$.

Indicates the availability of one of the Honduran

Emerald common food sources in the height stratum where most individuals of this cactus species were concentrated $(0-7.5 \mathrm{~m})$. Shrub strata encompasses plant species that are Honduran Emerald feeding source or nesting substrate.

A complementary value to complexity of a stand that represents the cover wildlife uses (Nudds 1977). It may indicate the potential cover that may serve the Honduran Emerald for several purposes such as predation protection or nesting attributes. To incorporate the composition of Agalta's plant community.

To incorporate the composition of Agalta's plant community.

To incorporate the composition of Agalta's plant community.

To incorporate the composition of Agalta's plant community.

Indicates the availability of plant species that may be used by Honduran Emeralds as a food resource.

Indicates the extent of the property that holds the mosaic of tropical dry forest habitat and cattle farm use areas.

Indicates plant species diversity. 
Table 2. Honduran Emerald (Amazilia luciae) top detection probability and abundance models, and abundance estimates for two sampling periods in the Agalta Valley, during 2014-2015 at 174 sampled point locations (48.7 ha). Mean values with SD for detection and abundance per point also shown. A complete AICc table of all fitted models of detection and abundance can be found in Appendices 2 and 3.

\begin{tabular}{|c|c|c|c|c|c|c|}
\hline \multirow[t]{2}{*}{ Sampling period } & \multicolumn{2}{|c|}{$\beta(\mathrm{SE})$} & \multirow{2}{*}{$\begin{array}{l}\text { Mean detection } \\
\text { per point (SD) }\end{array}$} & \multirow{2}{*}{$\begin{array}{l}\text { Mean } \\
\text { abundance per } \\
\text { point (SD) }\end{array}$} & \multirow{2}{*}{$\begin{array}{l}\text { Local } \\
\text { abundance }\end{array}$} & \multirow{2}{*}{$\begin{array}{l}95 \% \text { Confidence } \\
\text { intervals }\end{array}$} \\
\hline & $\mathrm{p}^{\dagger}$ & $\lambda^{\dagger}$ & & & & \\
\hline $\begin{array}{l}\text { September-December } \\
\text { p(Julian date) } \lambda\left(\text { Shrub-sapling density }{ }^{\S}\right)\end{array}$ & $-0.80(0.27)$ & $0.77(0.24)$ & $0.23(0.12)$ & $0.39(0.20)$ & 68 & $46-110$ \\
\hline $\begin{array}{l}\text { March-April } \\
\left.\text { p(Julian date }{ }^{\S}\right) \lambda(\text { Cacti structural diversity) }\end{array}$ & $-0.44(0.26)$ & $0.38(0.13)$ & $0.15(0.19)$ & $0.96(0.38)$ & 167 & $107-242$ \\
\hline $\begin{array}{l}\text { Detection probability } \\
\text { Abundance } \\
{ }^{\text {S Variable with quadratic term }}\end{array}$ & & & & & & \\
\hline
\end{tabular}

The probability of detecting a Honduran Emerald declined over time (Julian date) during the first two sampling periods (Fig. 3). During the second sampling period this decline was best characterized by a polynomial model with a quadratic term. Mean detection probability was the highest in the first sampling period (Table 2). Models constructed using data collected during our third sampling period were unable to estimate detection probability and abundance. We expect this is due to the lower number of detections. As such, we did not attempt further modeling using data collected during the third survey period.

Fig. 3. Honduran Emerald (Amazilia luciae) detection probability varied with Julian date, with a higher mean detection probability during September-December 2014 (left) than March-April 2015 (right). Graphs represent the topranked models for each survey period, and gray lines represent $95 \%$ confidence intervals.
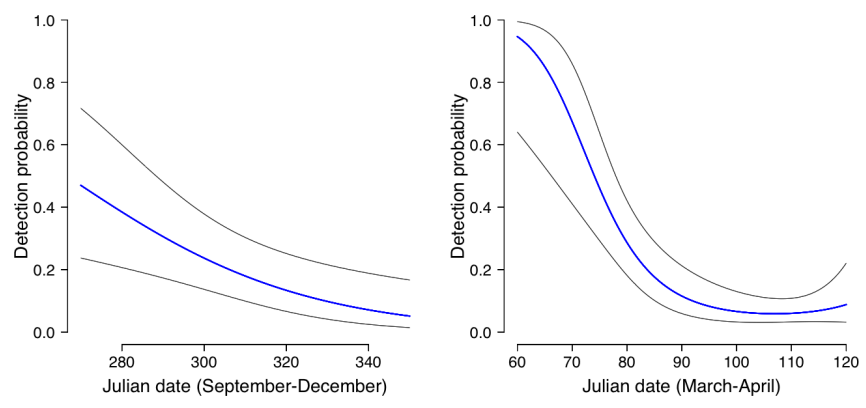

During our first sampling period, Honduran Emeralds were most abundant at locations with greater shrub-sapling density. This relationship was described best with a polynomial model including a quadratic term. This positive relationship (Table 2; Fig. 4) appeared to peak around 200 stems/ha, beyond which our model was not able to characterize a relationship. During our second sampling period, Honduran Emeralds were most abundant at locations with greater cacti structural diversity (Table 2; Fig. 4). Cacti structural diversity suggested that cacti at the lower strata between zero and seven meters were more prevalent with mean $22.62 \pm 15.17 \%$ SD for all points used during sampling period two $(\mathrm{N}=57$ points). These values of cacti structural diversity represent the used points with mean cacti height of 2.47 $\pm 1.66 \mathrm{~m}$ (range $=1-8.2 \mathrm{~m})$, total cacti density of all species of $235.44 \pm 89.84$ individuals/ha (range $=40-400)$, and cacti species richness of $2.09 \pm 1.1$ (range $=0-4$ species) where Opuntia hondurensis and Pilosocereus leucocephalus were the most frequent cacti species in the points. The highest local abundance was estimated during the second sampling period, albeit this period had the lowest detection probability (Table 2). Models from both sampling periods were not overdispersed (c-hat $=1.01$ sampling period one, and 0.99 for sampling period two) and had good fit according to the sums of squares, Chi-square, and Freeman Tukey statistics ( $\mathrm{p}>0.05)$.

Fig. 4. Expected abundance of Honduran Emerald (Amazilia luciae) in the Agalta Valley was most influenced by shrubsapling density during September-December 2014 (left) and most influenced by cacti structural diversity during MarchApril 2015 (right). Gray lines indicate 95\% confidence intervals.
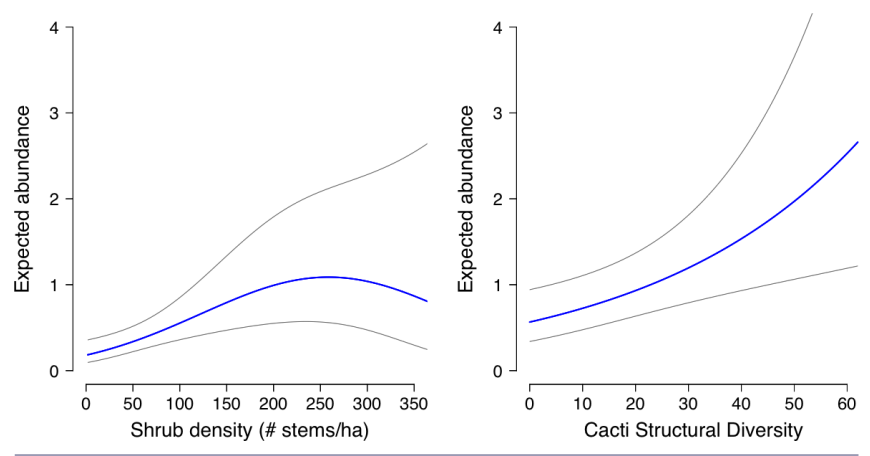

Our t-test results indicated that the proportion of the cactus Pilosocereus leucocephalus, relative to other cacti at a given plot, was higher at used points (Mean $=0.2 ; \mathrm{SD}=0.27$; Table 3 ) compared with unused points $($ Mean $=0.08 ; \mathrm{SD}=0.18$; Table 3 ). We propose the following variables to be included in future studies: cacti structural diversity, dominance (IVI) of Casearia nitida, Eugenia hondurensis, species richness of woody plants, epiphyte tree count, Holdridge Complexity Index, stems under 3 $\mathrm{cm} \mathrm{DBH}$, and patch size. These variables approached the threshold of significance in our t-tests that evaluated sites with 
Table 3. Comparison of vegetation variables between point count locations that were used and unused by Honduran Emeralds ( $A m a z i l i a$ luciae) in the Agalta Valley during 2014-2015.

\begin{tabular}{|c|c|c|c|c|c|c|c|c|c|c|}
\hline \multirow[t]{2}{*}{ Vegetation variable } & \multicolumn{3}{|c|}{$\begin{array}{l}\text { Used point count locations } \\
(\mathrm{N}=86)\end{array}$} & \multicolumn{3}{|c|}{$\begin{array}{l}\text { Unused point count locations } \\
(\mathrm{N}=88)\end{array}$} & \multicolumn{2}{|c|}{ t-test statistics } & \multirow[b]{2}{*}{$\begin{array}{c}\mathrm{p} \text {-value } \\
\text { uncorrected }\end{array}$} & \multirow[b]{2}{*}{$\begin{array}{c}\mathrm{p} \text {-value } \\
\text { corrected }\end{array}$} \\
\hline & Mean & $\mathrm{SD}$ & Range & Mean & $\mathrm{SD}$ & Range & $\mathrm{t}$ & df & & \\
\hline $\begin{array}{l}\text { Proportion of Opuntia } \\
\text { hondurensis cacti }\end{array}$ & 0.49 & 0.33 & $0-1$ & 0.5 & 0.39 & $0-1$ & 0.21 & 168.58 & 0.84 & 1 \\
\hline $\begin{array}{l}\text { Holdridge Complexity } \\
\text { Index }\end{array}$ & 117.4 & 130.5 & $0.03-825.78$ & 122.27 & 155.75 & $0-758.51$ & 0.22 & 168.1 & 0.82 & 1 \\
\hline $\begin{array}{l}\text { Density of woody } \\
\text { stems }<3 \mathrm{~cm} \mathrm{DBH}\end{array}$ & 2092.1 & 1514.27 & $0-7340$ & 1934.32 & 1611.31 & $0-10280$ & -0.67 & 171.74 & 0.51 & 1 \\
\hline $\begin{array}{l}\text { IVI Eugenia } \\
\text { hondurensis }\end{array}$ & 13.46 & 28.56 & $0-142.37$ & 10.24 & 23.39 & $0-88.3$ & -0.81 & 164.08 & 0.42 & 1 \\
\hline Vegetation density (\%) & 59.14 & 29.06 & $0-100$ & 55.51 & 27.84 & $0-100$ & -0.84 & 171.26 & 0.4 & 1 \\
\hline Epiphyte presence & 6.35 & 8.3 & $0-47$ & 4.69 & 6.57 & $0-27$ & -1.4571 & 161.73 & 0.147 & 1 \\
\hline $\begin{array}{l}\text { Shrub-sapling density } \\
\text { (no. stems/ha) }\end{array}$ & 76.16 & 83.78 & $7.2-587.6$ & 58.96 & 64.47 & $1.8-456.4$ & -1.52 & 159.61 & 0.13 & 1 \\
\hline $\begin{array}{l}\text { Shannon Diversity } \\
\text { Index }\end{array}$ & 2.45 & 0.89 & $0-3.6$ & 2.2 & 1.09 & $0-5.24$ & -1.68 & 166.74 & 0.09 & 1.0 \\
\hline IVI Acacia picachensis & 42.62 & 54.46 & $0-200$ & 59.09 & 66.44 & $0-200$ & 1.79 & 166.96 & 0.08 & 1.0 \\
\hline $\begin{array}{l}\text { IVI Erythroxylum } \\
\text { areolatum }\end{array}$ & 16.12 & 29.89 & $0-143.03$ & 8.9 & 19.42 & $0-87$ & -1.89 & 145.45 & 0.06 & 0.86 \\
\hline $\begin{array}{l}\text { Woody plant species } \\
\text { richness }\end{array}$ & 11.83 & 4.55 & $1-20$ & 10.32 & 5.07 & $1-20$ & -2.07 & 170.77 & $0.04^{*}$ & 0.56 \\
\hline IVI Casearia nitida & 8.83 & 14.65 & $0-56.98$ & 5.03 & 9.71 & $0-53.52$ & -2.11 & 153.25 & $0.04 *$ & 0.5 \\
\hline $\begin{array}{l}\text { Cacti structural } \\
\text { diversity }\end{array}$ & 21.29 & 14.65 & $0-48.11$ & 14.96 & 15.41 & $0-61.36$ & -2.78 & 171.87 & $0.006^{*}$ & 0.09 \\
\hline $\begin{array}{l}\text { Proportion of } \\
\text { Pilosocereus } \\
\text { leucocephalus cacti }\end{array}$ & 0.2 & 0.27 & $0-1$ & 0.08 & 0.18 & $0-0.86$ & -3.54 & 149.09 & $0.0005^{*}$ & $0.007 *$ \\
\hline
\end{tabular}

and without presence of Honduran Emeralds (Table 3) and were within $\triangle$ AICc=4-7 (Table 4).

\section{DISCUSSION}

Our study revealed that shrub-sapling density and cacti structural diversity explained Honduran Emerald local abundance in tropical dry forest remnants of the Agalta Valley. In other parts of the species range, shrubs and cacti species have been highlighted as components of the tropical dry forest used by this species (Thorn et al. 2000, House 2004). In fact, it is well documented that shrub and cacti are ecologically important to many species of tropical hummingbirds for feeding, or perching close to feeding areas (Skutch 1958, Wolf 1964, Wolf and Stiles 1970, Feinsinger 1976, Hainsworth 1977, Snow and Snow 1986, Fraga 1989). In addition, small trees or saplings are considered to have suitable floral resources that are suitable for hummingbirds (Snow and Snow 1986). Honduran Emeralds' use of shrubs and cacti as a floral resource has been reported elsewhere (Anderson et al. 2010). The use of the shrub-sapling strata by Honduran Emeralds as a source of floral resources was observed previously in the Agalta Valley (Mora et al. 2016). Moreover, field observations during our study revealed that the species used floral resources of four shrub and two cacti species: Aphelandra scabra (Acanthaceae), Combretum fruticosum (Combretaceae), Pedilanthus tithymaloides (Euphorbiaceae), Cnidoscolus aconitifolius (Euphorbiaceae), and Opuntia hondurensis (Cactaceae) and Pilosocereus leucocephalus
(Cactaceae), respectively. Honduran Emeralds also used shrubsapling and cacti strata as nesting substrate (Rodríguez et al. 2016).

In addition to shrub-sapling density, cacti structural diversity most explained variation in Honduran Emerald abundance across our survey locations. This finding reinforces the previous observations and highlights the importance of cacti species as nesting and feeding sites (Anderson et al. 2010, Rodríguez et al. 2016). Furthermore, when all sampling periods were pooled, the percent cover of the cactus, Pilosocereus leucocephalus, was the only vegetation feature we measured that differed between used and unused points whereby used points had higher values. Our results regarding the influence of shrub-sapling density and cacti structural diversity on Honduran Emerald abundance should be considered in future studies that attempt to evaluate the influence of habitat conditions on the species fitness parameters (Johnson 2007). For example, most Honduran Emerald nests found in dry forest remnants in the Agalta Valley were placed in the shrubsapling strata (Rodríguez et al. 2016). But it remains unknown how shrub-sapling density or vegetation composition affects nest success. Our results in combination with those from studies that evaluate reproductive success and other fitness parameters can guide habitat management recommendations for the species.

We also found that the probability of detecting Honduran Emerald varied within sampling periods and that it was best explained by Julian date. Although we are uncertain why Julian 
Table 4. Honduran Emerald (Amazilia luciae) models of abundance in the Agalta Valley during 2014-2015 for the first (SeptemberDecember) and second (March-April) sampling periods. We present models up to $\triangle \mathrm{AICc}=7$, which illustrate microhabitat features that may influence Honduran Emerald abundance. Coefficients $(\beta)$ with SE in parenthesis and $85 \%$ confidence intervals $(C I)$ shown.

\begin{tabular}{|c|c|c|c|c|c|c|c|c|c|}
\hline \multirow[t]{2}{*}{ Model } & \multirow[t]{2}{*}{ Sampling period } & \multirow{2}{*}{$\frac{\beta(\mathrm{SE})}{\lambda}$} & \multirow{2}{*}{$\begin{array}{c}\text { CI } 85 \% \\
\lambda \\
\end{array}$} & \multirow[t]{2}{*}{$\mathrm{K}^{\dagger}$} & \multirow[t]{2}{*}{$\mathrm{AICc}$} & \multirow[t]{2}{*}{$\triangle \mathrm{AICc}$} & \multirow[t]{2}{*}{$\begin{array}{l}\mathrm{AICc} \\
\mathrm{Wt}^{\star}\end{array}$} & \multirow[t]{2}{*}{$\underset{\mathrm{Wt}^{\ddagger}}{\text { Cumulative }}$} & \multirow[t]{2}{*}{$\mathrm{LL}^{\S}$} \\
\hline & & & & & & & & & \\
\hline 1 & $\begin{array}{l}\text { September-December } \\
\lambda(\text { Shrub strata density) } \\
\lambda(\text { Shrub strata density) }\end{array}$ & $\begin{array}{l}0.77(0.24) \\
-015(0.08)\end{array}$ & $\begin{array}{c}0.42 ; 1.12 \\
-0.26 ;-0.04\end{array}$ & 5 & 348.70 & 0.00 & 0.64 & 0.64 & -169.17 \\
\hline 2 & $\lambda($ Shrub strata density) & $0.21(0.09)$ & $0.08 ; 0.35$ & 4 & 353.36 & 4.67 & 0.06 & 0.70 & -172.56 \\
\hline 3 & $\begin{array}{l}\lambda(\text { Stems under } 3 \mathrm{~cm}) \\
\lambda\left(\text { Stems under } 3 \mathrm{~cm}^{\prime}\right)\end{array}$ & $\begin{array}{l}-0.17(0.21) \\
-0.32(0.24)\end{array}$ & $\begin{array}{l}-0.47 ; 0.13 \\
-0.66 ; 0.02\end{array}$ & 5 & 354.81 & 6.11 & 0.03 & 0.73 & -172.23 \\
\hline 4 & $\lambda($ Stems under $3 \mathrm{~cm})$ & $-0.25(0.17)$ & $-0.50 ; 0.01$ & 4 & 355.22 & 6.52 & 0.02 & 0.75 & -173.49 \\
\hline 5 & $\lambda()$. & $-0.9(0.2)$ & $-1.19 ;-0.61$ & 3 & 355.33 & 6.63 & 0.02 & 0.77 & -174.59 \\
\hline 6 & $\begin{array}{l}\lambda(\text { Eugenia hondurensis }) \\
\lambda(\text { Eugenia hondurensis })\end{array}$ & $\begin{array}{l}-0.28(0.30) \\
0.12(0.08)\end{array}$ & $\begin{array}{l}-0.70 ; 0.15 \\
0.02 ; 0.23\end{array}$ & 5 & 355.41 & 6.72 & 0.02 & 0.80 & -172.53 \\
\hline 7 & $\begin{array}{l}\lambda(\text { Pilosocereus leucocephalus }) \\
\text { March-April }\end{array}$ & $0.17(0.12)$ & $0.001 ; 0.35$ & 4 & 355.48 & 6.78 & 0.02 & 0.82 & -173.62 \\
\hline 1 & $\lambda$ (Cacti structural diversity) & $0.38(0.13)$ & $0.20 ; 0.57$ & 5 & 452.75 & 0.00 & 0.47 & 0.47 & -221.20 \\
\hline 2 & $\begin{array}{l}\lambda(\text { Cacti structural diversity) } \\
\lambda(\text { (Cacti structural diversity })\end{array}$ & $\begin{array}{l}0.37(0.14) \\
0.02(0.12)\end{array}$ & $\begin{array}{l}0.18 ; 0.57 \\
-0.15 ; 0.19\end{array}$ & 6 & 454.87 & 2.11 & 0.16 & 0.63 & -221.18 \\
\hline 3 & $\begin{array}{l}\lambda(\text { Pilosocereus leucocephalus }) \\
\lambda(\text { Pilosocereus leucocephalus })\end{array}$ & $\begin{array}{c}0.61(0.23) \\
-0.32(0.14)\end{array}$ & $\begin{array}{c}0.27 ; 0.94 \\
-0.52 ;-0.12\end{array}$ & 6 & 456.87 & 4.12 & 0.06 & 0.69 & -222.18 \\
\hline 4 & $\begin{array}{l}\lambda(\text { Epiphyte tree count }) \\
\lambda(\text { Epiphyte tree count })\end{array}$ & $\begin{array}{c}0.58(0.24) \\
-0.22(0.13)\end{array}$ & $\begin{array}{c}0.24 ; 0.92 \\
-0.41 ;-0.04\end{array}$ & 6 & 457.02 & 4.27 & 0.06 & 0.74 & -222.26 \\
\hline 5 & $\begin{array}{l}\lambda(\text { Patch size }) \\
\lambda(\text { Patch size })\end{array}$ & $\begin{array}{c}0.53(0.21) \\
-0.26(0.13)\end{array}$ & $\begin{array}{c}0.22 ; 0.84 \\
-0.44 ;-0.08\end{array}$ & 6 & 457.66 & 4.91 & 0.04 & 0.78 & -222.58 \\
\hline 6 & $\begin{array}{l}\lambda(\text { Opuntia hondurensis }) \\
\lambda(\text { Opuntia hondurensis })\end{array}$ & $\begin{array}{l}0.03(0.14) \\
-0.40(0.17)\end{array}$ & $\begin{array}{l}-0.17 ; 0.23 \\
-0.64 ;-0.16\end{array}$ & 6 & 458.01 & 5.26 & 0.03 & 0.82 & -222.75 \\
\hline 7 & $\begin{array}{l}\lambda(\mathrm{HCI}) \\
\lambda\left(\mathrm{HCI}^{1}\right)\end{array}$ & $\begin{array}{l}0.25(0.21) \\
-0.34(0.19)\end{array}$ & $\begin{array}{l}-0.05 ; 0.55 \\
-0.62 ;-0.06\end{array}$ & 6 & 458.32 & 5.56 & 0.03 & 0.85 & -222.91 \\
\hline $\begin{array}{l}8 \\
9\end{array}$ & $\begin{array}{l}\lambda(\text { Epiphyte tree count }) \\
\lambda(.)\end{array}$ & $\begin{array}{l}0.17(0.10) \\
-0.11(0.19)\end{array}$ & $\begin{array}{c}0.02 ; 0.32 \\
-0.39 ; 0.17\end{array}$ & $\begin{array}{l}5 \\
4\end{array}$ & $\begin{array}{l}459.50 \\
459.72\end{array}$ & $\begin{array}{l}6.75 \\
6.97\end{array}$ & $\begin{array}{l}0.02 \\
0.01\end{array}$ & $\begin{array}{l}0.86 \\
0.88\end{array}$ & $\begin{array}{l}-224.57 \\
-225.74\end{array}$ \\
\hline $\begin{array}{l}\text { Numb } \\
\text { Weigh } \\
\text { \$ log-lik } \\
\text { I Variab }\end{array}$ & $\begin{array}{l}\text { of parameters } \\
\text { hood } \\
\text { with a quadratic term }\end{array}$ & & & & & & & & \\
\hline
\end{tabular}

date had a negative influence on Honduran Emerald detection, we consider that detectability was influenced negatively by variability in the detection history for any survey location, e.g., one individual detected in one point versus three in a different point (Royle 2004b, Dénes et al. 2015). In turn, we propose that the variability in detection history within each sampling period may reflect the patterns of hummingbird movement within the heavily fragmented study area that are driven by seasonal variability and availability of resources. That is, the need for individuals to periodically shift activity centers throughout the year in response to shifting floral resources, may translate to variability in detection history for any given survey location. Past studies have indicated how hummingbird detections vary per month, most likely because of flower availability driven by vegetation phenology in these environments (Arizmendi and Ornelas 1990, Murphy and Lugo 1995, Rodríguez-Flores and Wethington 2017). Furthermore, if floral resources are patchily distributed, hummingbird movements could be influenced by the landscape configuration making their availability and detection more variable (Hadley and Betts 2009, Volpe et al. 2014). Future studies that examine Honduran Emerald ecology at the territory or home range scales throughout the entire annual cycle will likely provide insight needed to understand mechanisms that explain the influence of Julian date on detection probability.
Our local abundance estimates extrapolated to the extent of dry forest remnants (2840 Honduran Emerald individuals, CI 95\% 1880-4720) are comparable to population estimates for the Agalta Valley presented in the Endangered Species Act ruling for the species (United States Fish and Wildlife Service 2015). However, we suggest a caveat to this observation, which is the observed variability of abundance across our survey points that was influenced by microhabitat features described above. This influence reflects the variation of habitat conditions throughout the study area, thus making the assumption of a uniform distribution of Honduran Emeralds in the dry forest remnants difficult to meet (Kéry and Schmidt 2008). Nevertheless, our population estimate is valuable for understanding the current conservation status of this species in the Agalta Valley. The rate at which dry forest is being converted to cattle farms in the Agalta Valley will result in continued habitat loss that will negatively influence Honduran Emerald local abundance and ultimately its population dynamics. Between 2016 and 2017, two years after our study was conducted, at least 30 ha of dry forest were lost within our study sites based on a global forest cover change database (Hansen et al. 2013). As such, our abundance estimate supports the assertion by others that conservation of existing habitat is needed to prevent further population decline (Anderson et al. 
2010, Mora et al. 2016). Such conservation actions should begin immediately and be implemented at biologically meaningful scales.

Our study is the first to account for imperfect detection in abundance estimates for the endangered Honduran Emerald. We provided additional insight on the species abundance patterns by estimating detection probability with a hierarchical modeling approach. In doing so, we avoided the assumption that detection probability is always perfect, and we correct by estimating the variability in detection to obtain an abundance estimate (Kéry and Schmidt 2008). We stress that future studies or monitoring aimed at estimating Honduran Emerald local abundance or population size use a framework that accounts for imperfect detection (Kéry and Schmidt 2008). Indeed, future Honduran Emerald surveys could be conducted when detection probability is expected to be high, i.e., September-December $p=0.23 \pm 0.12$ ). However, to relate abundance with reproductive success and assess habitat quality, surveys should be conducted within the breeding season (January-April; Rodríguez et al. 2016) and should include quantification of cacti structural diversity and shrub-sapling strata density. Equally important to future monitoring will be to conduct multiple visits to each survey point within these months, e.g., two-three visits, to counter the factors that contribute to imperfect detection (Royle 2004b). Parallel to the considerations in survey design to model Honduran Emerald abundance, our characterization of the vegetation at points used by Honduran Emeralds can be informative for future studies and conservation actions (Table 4). The microhabitat values we quantified may serve as a guideline for habitat restoration activities (Janzen 1988). Subsequently, different habitat managed treatments could be evaluated to assess their effectiveness for restoring and maintaining Honduran Emerald habitat.

Our research revealed how microhabitat features influence the local abundance of the endangered Honduran Emerald and how the use of modeling techniques for avian counts can be fine-tuned to inform the species status in the Agalta Valley. Similar work should be conducted in the other valleys where the Honduran Emerald is known to occur to obtain insight to the species status across its entire distributional range. Our study framework could be useful in other dry forests in the valleys of Aguán and Telica, which share similar composition and structure to the Agalta Valley (Anderson et al. 2010). Furthermore, because of past detections of the species in ecotones between dry forest and pineoak in the Agalta Valley, a study that compares Honduran Emerald abundance between these two cover types should be conducted (Mora et al. 2016). Until more insight on Honduran Emerald ecology is gained from additional research and monitoring, conservation activities for this species should target dry forest protection and restoration, as well as promote dense shrub-sapling strata and structurally diverse cacti components. Periodic monitoring of Honduran Emerald response to conservation activities is warranted, but in a geography with limited conservation resources we urge that the immediate priority should be to focus available funding on working with landowners to protect existing dry forest and to restore additional areas.

Although our study focused on the relationship between microhabitat features and the abundance of a single species, our findings provide a broad reminder of the implications species declines can potentially have on the intricate codependencies that exist between plant communities and their associated pollinators. For instance, Honduran Emerald local abundance was positively influenced by cacti structural diversity that included Opuntia hondurensis, suggesting that this imperiled hummingbird is likely a key pollinator of this dry forest endemic plant, as seen in other Opuntia sp. pollinated by hummingbirds (Díaz and Cocucci 2003). Researchers have previously highlighted the importance of hummingbirds as "generators of biodiversity" due to their pollination services (Arizmendi 2017). We are unaware of the magnitude of the role the Honduran Emerald plays as a pollinator of Opuntia hondurensis and other dry forest species, but it is well known that reductions in pollinator species diversity can have negative impacts on plant communities (Potts et al. 2010). For example, increasing the functional diversity of both pollinators and plants led to the persistence of more diverse plant communities (Fontaine et al. 2006). Moreover, reductions in pollinator functional diversity has the potential to initiate plant population declines or extinctions (Kearns et al. 1998). With tropical dry forests being floristically distinct across the Americas (Banda et al. 2016), understanding how hummingbirds and dry forest plant communities interact will need to go hand-in-hand to guarantee effective conservation of these tropical dry forests and the species they support. Indeed, studies that examine how reciprocal effects of pollinator species declines and plant species diversity influences the long-term stability of tropical dry forest ecosystems are warranted. Conservation efforts such as the one ongoing in the Agalta Valley, that acknowledge the needs of both human and natural communities, should increase awareness for the importance of plant-animal interactions and the need to work at both microhabitat and landscape scales to most effectively conserve those interspecific relationships.

Responses to this article can be read online at: http://www.ace-eco.org/issues/responses.php/1321

\section{Acknowledgments:}

We are grateful for the support of the community and producers of the tropical dry forest in San Esteban and Gualaco, department of Olancho in Honduras. We thank the valuable effort, field research, and herbarium work of Rosa Ramírez, Denis Padilla, as well as the team of the TEFH herbarium of the Universidad Nacional Autónoma de Honduras. We thank Elvin Urbina for his field research support. Special thanks to the team of the Asociacion de Investigación para el Desarrollo Ecológico y Socioeconómico ( ASIDE) and to American Bird Conservancy for their interest and support to conservation of the Honduran Emerald in Agalta Valley. Camila Gómez and John Herbert offered helpful comments and advice to improve this manuscript. Funding for this study was provided and managed by Inversión Estratégica de Honduras (INVESTH-MCA) and the Interamerican Development Bank (IDB).

\section{LITERATURE CITED}

Anderson, D. L., D. M. Atwood, M. A. Bonta, D. Germer, R. E. Hyman, D. Medina, R. Steiner, and S. Thorn. 2013. Comments 
on US Fish and Wildlife Service, proposed endangered listing of the Honduran Emerald (Amazilia luciae). Docket No. FWS-R9-ES 2009-0094 Regulations. [online] URL: http://www.regulations. gov/\#!documentDetail;D=FWS-R9-ES-2009-0094-0008

Anderson, D. L., P. House, R. E. Hyman, R. Steiner, H. R. Hawkins, S. Thorn, M. J. Rey, M. R. Espinal, and L. E. Marineros. 2010. Rediscovery of the Honduran Emerald Amazilia luciae in western Honduras: insights on the distribution, ecology, and conservation of a 'Critically Endangered' hummingbird. Bird Conservation International 20:255-262. http://dx.doi.org/10.1017/ S0959270910000389

Anderson, D. L., and R. E. Hyman. 2007. Honduran Emerald conservation expedition: protecting the Honduran Emerald Hummingbird and its habitat. The Explorer's Club Flag \# 51 official report. The Explorer's Club, New York, New York, USA. [online] URL: https://explorers.org/flag_reports/Flag51-Hyman. pdf

Apps, C. D., B. N. McLellan, J. G. Woods, and M. F. Proctor. 2004. Estimating grizzly bear distribution and abundance relative to habitat and human influence. Journal of Wildlife Management 68:138-152. http://dx.doi.org/10.2193/0022-541X(2004)068[0138: EGBDAA]2.0.CO;2

Arizmendi, M. 2017. Introduction to symposium. Page 1 in S. M. Wethington and M. Arizmendi, editors. Hummingbirds in a changing world: Why hummingbird conservation matters! VI Partners in Flight International Conference, San José, Costa Rica.

Arizmendi, M., and J. F. Ornelas. 1990. Hummingbirds and their floral resources in a tropical dry forest in Mexico. Biotropica 22:172-180. http://dx.doi.org/10.2307/2388410

Arnold, T. W. 2010. Uninformative parameters and model selection using Akaike's information criterion. Journal of Wildlife Management 74:1175-1179. http://dx.doi.org/10.2193/2009-367

Banco Interamericano de Desarrollo. 2009. Informe de gestion ambiental y social (IGAS): programa de mejoramiento vial corridor agrícola. Banco Interamericano de Desarrollo de Honduras.

Banda, K., A. Delgado-Salinas, K. G. Dexter, R. LinaresPalomino, A. Oliveira-Filho, D. Prado, M. Pullan, C. Quintana, R. Riina, G. M. Rodríguez, J. Weintritt, P. Acevedo-Rodríguez, J. Adarve, E. Álvarez, A. Aranguren, J. C. Arteaga, G. Aymard, A. Castaño, N. Ceballos-Mago, A. Cogollo, H. Cuadros, F. Delgado, W. Devia, H. Dueñas, L. Fajardo, Á. Fernández, M. Á. Fernández, J. Franklin, E. H. Freid, L. A. Galetti, R. Gonto, R. González-M., R. Graveson, E. H. Helmer, Á. Idárraga, R. López, H. Marcano-Vega, O. G. Martínez, H. M. Maturo, M. McDonald, K. McLaren, O. Melo, F. Mijares, V. Mogni, D. Molina, N. Moreno, J. M. Nassar, D. M. Neves, L. J. Oakley, M. Oatham, A. R. Olvera-Luna, F. F. Pezzini, O. J. Reyes, M. E. Ríos, O. Rivera, N. Rodríguez, A. Rojas, T. Särkinen, R. Sánchez, M. Smith, C. Vargas, B. Villanueva, and R. T. Pennington. 2016. Plant diversity patterns in neotropical dry forests and their conservation implications. Science 353:1383-1387. http://dx.doi.org/10.1126/ science.aaf5080

Bibby, C. J., N. D. Burgess, D. A. Hill, and S. Mustoe. 1992. Bird census techniques. Academic, London, UK.
BirdLife International. 2016. Honduran Emerald Amazilia luciae. The IUCN Red list of threatened species. IUCN Global Species Programme Red List Unit, Cambridge, UK. http://dx.doi. org/10.2305/IUCN.UK.2016-3.RLTS.T22687529A93156708.en

Blackie, R., C. Baldauf, D. Gautier, D. Gumbo, H. Kassa, N. Parthasarathy, F. Paumgarten, P. Sola, S. Pulla, P. Waeber, and T. Sunderland. 2014. Tropical dry forests: the state of global knowledge and recommendations for future research. CIFOR, Bogor, Indonesia. [online] URL: http://www.cifor.org/publications/ pdf_files/WPapers/DPBlackie1401.pdf?_ga=1.51025004.45351557.1403802494

Burnham, K. P., and D. R. Anderson. 2002. Model selection and multimodel inference. Springer-Verlag, New York, New York, USA. http://dx.doi.org/10.1007/b97636

Bush, M. B., D. R. Piperno, P. A. Colinvaux, P. E. de Oliveira, L. A. Krissek, M. C. Miller, and W. E. Rowe. 1992. A 14 300-yr paleoecological profile of a lowland tropical lake in Panama. Ecological Monographs 62:251-275. http://dx.doi.org/10.2307/2937095

Cahill, J. R. A., and E. Matthysen. 2007. Habitat use by two specialist birds in high-Andean Polylepis forests. Biological Conservation 140:62-69. http://dx.doi.org/10.1016/j.biocon.2007.07.022

Chandler, R. B., J. A. Royle, and D. I. King. 2011. Inference about density and temporary emigration in unmarked populations. Ecology 92:1429-1435. http://dx.doi.org/10.1890/10-2433.1

Collen, B., N. Pettorelli, J. E. M. Baillie, and S. M. Durant. 2013. Biodiversity monitoring and conservation: bridging the gaps between global commitment and local action. Pages 23-37 in $\mathrm{B}$. Collen, N. Pettorelli, J. E. M. Baillie, and S. M. Durant, editors. Biodiversity monitoring and conservation: bridging the gap between global commitment and local action. John Wiley \& Sons, Chichester, UK. http://dx.doi.org/10.1002/9781118490747

Dénes, F. V., L. F. Silveira, and S. R. Beissinger. 2015. Estimating abundance of unmarked animal populations: accounting for imperfect detection and other sources of zero inflation. Methods in Ecology and Evolution 6:543-556. http://dx.doi.

org/10.1111/2041-210X.12333

Díaz, L., and A. A. Cocucci. 2003. Functional gynodioecy in Opuntia quimilo (Cactaceae), a tree cactus pollinated by bees and hummingbirds. Plant Biology 5:531-539. http://dx.doi.org/10.1055/ s-2003-44783

eBird. 2017. eBird basic dataset: EBD_relNov_2017. Cornell Lab of Ornithology, Ithaca, New York, USA.

Espinal, M., and J. Mora. 2012. Estrategia y plan de acción para la conservación del hábitat del Colibrí Esmeralda (Amazilia luciae) en el Valle de Agalta, en el departamento de Olancho. SOPTRAVI, Tegucigalpa, Honduras.

Espírito-Santo, M. M., L. Olívio-Leite, F. de Siqueira Neves, Y. R. Ferreira-Nunes, M. A. Zazá-Borges, L. A. Dolabela-Falcão, F. Fonseca-Pezzini, R. Louro-Berbara, H. Maia-Valério, G. W. Fernandes, M. Reinaldo-Leite, C. M. Santos-Clemente, and M. Esdras-Leite. 2014. Tropical dry forests of Northern Minas Gerais, Brazil: diversity, conservation status, and natural regeneration. Pages 69-81 in A. Sánchez-Azofeifa, J. S. Powers, W. G. Fernandes, and M. Quesada, editors. Tropical dry forests 
in the Americas: ecology, conservation, and management. CRC Press, Taylor \& Francis Group, Boca Raton, Florida, USA.

Farnsworth, G. L., K. H. Pollock, J. D. Nichols, T. R. Simons, J. E. Hines, and J. R. Sauer. 2002. A removal model for estimating detection probabilities from point-count surveys. Auk 119:414-425. http://dx.doi.org/10.1642/0004-8038(2002)119[0414: ARMFED]2.0.CO;2

Feinsinger, P. 1976. Organization of a tropical guild of nectarivorous birds. Ecological Monographs 46:257-291. http:// dx.doi.org/10.2307/1942255

Fiske, I., and R. Chandler. 2011. 'unmarked': an R package for fitting hierarchichal models of wildlife occurence and abundance. Journal of Statistical Software 43:1-23. http://dx.doi. org/10.18637/jss.v043.i10

Fontaine, C., I. Dajoz, J. Meriguet, and M. Loreau. 2006. Functional diversity of plant-pollinator interaction webs enhances the persistence of plant communities. PLoS Biology (1): e1. http://dx.doi.org/10.1371/journal.pbio.0040001

Fraga, R. M. 1989. Interactions between nectarivorous birds and the flowers of Aphelandra sinclairiana in Panama. Journal of Tropical Ecology 5:19-26. http://dx.doi.org/10.1017/S0266467400003187

García-Villacorta, R. 2009. Diversidad, composición y estructura de un hábitat altamente amenazado: los bosques estacionalmente secos de Tarapoto, Perú. Revista Peruana de Biología 16:81-92. http://dx.doi.org/10.15381/rpb.v16i1.177

Gentry, A. H. 1995. Diversity and floristic composition of neotropical dry forests. Pages 146-190 in S. H. Bullock, H. A. Mooney, and E. Medina, editors. Seasonally dry tropical forests. Cambridge University Press, Cambridge, UK. http://dx.doi. org/10.1017/CBO9780511753398.007

Gómez-Montes, C., and N. J. Bayly. 2010. Habitat use, abundance, and persistence of Neotropical migrant birds in a habitat matrix in northeast Belize. Journal of Field Ornithology 81:237-251. http://dx.doi.org/10.1111/j.1557-9263.2010.00269.x

Gómez-Pompa, A., J. S. Flores, and V. Sosa. 1987. The "Pet Kot": a man-made tropical forest of the Maya. Interciencia 12:10-15.

Hadley, A. S., and M. G. Betts. 2009. Tropical deforestation alters hummingbird movement patterns. Biology Letters 5:207-210. http://dx.doi.org/10.1098/rsbl.2008.0691

Hainsworth, F. R. 1977. Foraging efficiency and parental care in Colibri coruscans. Condor 79:69-75. http://dx.doi.org/10.2307/1367532

Hansen, M. C., P. V. Potapov, R. Moore, M. Hancher, S. A. Turubanova, A. Tyukavina, D. Thau, S. V. Stehman, S. J. Goetz, T. R. Loveland, A. Kommareddy, A. Egorov, L. Chini, C. O. Justice, and J. R. G. Townshend. 2013. High-resolution global maps of 21st-century forest cover change. Science 342: 850-854. http://dx.doi.org/10.1126/science.1244693

Heikkinen, R. K., M. Luoto, R. Virkkala, and K. Rainio. 2004. Effects of habitat cover, landscape structure and spatial variables on the abundance of birds in an agricultural-forest mosaic. Journal of Applied Ecology 41:824-835. http://dx.doi.org/10.1111/ j.0021-8901.2004.00938.x
Holdridge, L. R., W. C. Grenke, W. H. Hatheway, T. Liang, and J. Tosi. 1971. Forest environments in tropical life zones: a pilot study. Pergamon Press, New York, New York, USA.

Holm, S. 1979. A simple sequentially rejective multiple test procedure. Scandinavian Journal of Statistics 6:65-70.

House, P. R. 2004. Informe sobre el Colibrí Esmeralda en quebrada Seca, Arenal. Fundación Ecológica Montaña de Santa Bárbara, Honduras. [online] URL: http://www.fecomol.org/pdf/ informe_quebrada_seca_arenal.pdf

Howell, S. N., and S. Webb. 1989. Notes on the Honduran Emerald. Wilson Bulletin 101:642-643.

Hurvich, C. M., and C. Tsai. 1989. Regression and time series model selection in small samples. Biometrika 76:297-307. http:// dx.doi.org/10.1093/biomet/76.2.297

INGTELSIG. 2013. Abundancia, distribución y ecología del Colibri Esmeralda (Amazilia luciae) en el bosque seco de Santa Bárbara, Honduras. INGTELSIG, Siguatepeque, Honduras.

Iwata, T., M. Inoue, S. Nakano, H. Miyasaka, A. Doi, and A. P. Covich. 2003. Shrimp abundance and habitat relationships in tropical rain-forest streams, Sarawak, Borneo. Journal of Tropical Ecology 19:387-395. http://dx.doi.org/10.1017/S0266467403003432

Janzen, D. H. 1988. Management of habitat fragments in a tropical dry forest: growth. Annals of the Missouri Botanical Garden 75:105-116. http://dx.doi.org/10.2307/2399468

Jiménez, J., O. Aguirre, and H. Kramer. 2001. Análisis de la estructura horizontal y vertical en un ecosistema multicohortal de pino-encino en el norte de México. Investigación Agraria, Sistemas y Recursos Forestales 10:3-7.

Johnson, M. D. 2007. Measuring habitat quality: a review. Condor 109:489-504. http://dx.doi.org/10.1650/8347.1

Kearns, C. A., D. W. Inouye, and N. M. Waser. 1998. Endangered mutualisms: the conservation of plant-pollinator interactions. Annual Review of Ecology and Systematics 29:83-112. http://dx. doi.org/10.1146/annurev.ecolsys.29.1.83

Kéry, M., and J. A. Royle. 2016. Applied hierarchical modeling in ecology. Academic, London, UK.

Kéry, M., and B. Schmidt. 2008. Imperfect detection and its consequences for monitoring for conservation. Community Ecology 9:207-216. http://dx.doi.org/10.1556/ComEc.9.2008.2.10

Lawrence, G. N. 1867. Descriptions of five new species of Central American birds. Proceedings of the Academy of Natural Sciences of Philadelphia 19:232-234.

Lynch, J. 1995. Effects of point count duration, time of day and aural stimuli on detectability of migratory and resident bird species in Quintana Roo, Mexico. Pages 1-6 in C. J. Ralph, J. R. Sauer, and S. Droege, editors. Monitoring bird populations by point counts. General Technical Report PSW-GTR-149. Pacific Southwest Research Station, Albany, California, USA.

Marsh, D. M., and P. C. Trenham. 2008. Current trends in plant and animal population monitoring. Conservation Biology 22:647-655. http://dx.doi.org/10.1111/j.1523-1739.2008.00927.x 
Martin, T. E., C. Paine, C. J. Conway, W. M. Hochachka, P. Allen, and W. Jenkins. 1997. Breeding biology research and monitoring database (BBIRD) field protocol. Montana Cooperative Wildlife Unit, Missoula, Montana, USA.

Mazerolle, M. J. 2017. Model selection and multimodel inference based on (Q) $A I C(c)$. R package version 2.1-1. [online] URL: https://cran.r-project.org/package=AICcmodavg

Mora, J. M., M. R. Espinal, L. D. Germer, and L. I. López. 2016. Abundancia relativa del Colibrí Esmeralda (Amazilia luciae) en su comunidad de aves en el Valle de Agalta, Olancho, Honduras. Ceiba 54:127-138. http://dx.doi.org/10.5377/ceiba.v54i2.3284

Mora-Donjuán, C. A., E. A. Rubio-Camacho, E. AlanísRodríguez, J. Jiménez-Pérez, M. González-Tagle, J. M. MataBalderas, and A. Mora-Olivo. 2014. Composición y diversidad vegetal de un área de matorral desértico micrófilo con historial pecuario en el noreste de México. Polibotánica 38:53-66.

Mostacedo, B., and T. S. Fredericksen. 2000. Métodos básicos de muestreo y análisis en ecología vegetal. Editora El País, Santa Cruz, Bolivia. [online] URL: http://www.bio-nica.info/biblioteca/ mostacedo2000ecologiavegetal.pdf

Murphy, P. G., and A. E. Lugo. 1995. Dry forests of Central America and the Caribbean. Pages 9-34 in S. H. Bullock, H. A. Mooney, and E. Medina, editors. Seasonally dry tropical forests. Cambridge University Press, Cambridge, UK. http://dx.doi. org/10.1017/CBO9780511753398.002

NASA LP DAAC. 2011. ASTER Global DEM V2. U.S. Geological Survey, Washington, D.C., USA. [online] URL: http:// gdex.cr.usgs.gov/gdex/

Nassar, J. M., J. P. Rodríguez, A. Sánchez-Azofeifa, T. Garvin, and M. Quesada. 2008. Manual of methods: human, ecological and biophysical dimensions of tropical dry forests. Instituto Venezolano de Investigaciones Científicas, Caracas, Venezuela.

Nichols, J. D., and D. I. Mackenzie. 2004. Abundance estimation and conservation biology. Animal Biodiversity and Conservation 27:437-439.

Nudds, T. D. 1977. Quantifying the vegetative structure of wildlife cover. Wildlife Society Bulletin 5:113-117.

Paradis, E., and K. Schliep. 2018. ape 5.0: an environment for modern phylogenetics and evolutionary analyses in $\mathrm{R}$. Bioimformatics 1-3.

Pardini, R., S. M. de Souza, R. Braga-Neto, and J. P. Metzger. 2005. The role of forest structure, fragment size and corridors in maintaining small mammal abundance and diversity in an Atlantic forest landscape. Biological Conservation 124:253-266. http://dx.doi.org/10.1016/j.biocon.2005.01.033

Potts, S. G., J. C. Biesmeijer, C. Kremen, P. Neumann, O. Schweiger, and W. E. Kunin. 2010. Global pollinator declines: trends, impacts and drivers. Trends in Ecology and Evolution 25:345-353. http://dx.doi.org/10.1016/j.tree.2010.01.007

Pretzsch, H. 2009. Forest dynamics, growth and yield. Springer, London, UK. http://dx.doi.org/10.1007/978-3-540-88307-4_1

R Core Team. 2017. R: a language and environment for statistical computing. R Foundation for Statistical Computing, Vienna, Austria. [online] URL: http://www.r-project.org/
Renfrew, R. B., and C. A. Ribic. 2008. Multi-scale models of grassland passerine abundance in a fragmented system in Wisconsin. Landscape Ecology 23:181-193. http://dx.doi. org/10.1007/s10980-007-9179-2

Rivera-Milán, F. F., P. Bertuol, F. Simal, and B. L. Rusk. 2015. Distance sampling survey and abundance estimation of the critically endangered Grenada Dove (Leptotila wellsi). Condor 117:87-94. http://dx.doi.org/10.1650/CONDOR-14-131.1

Rodríguez, F., D. Escoto, T. Mejía-Ordóñez, L. Ferrufino-Acosta, S. Y. Cruz, and J. L. Larkin. 2016. Notas sobre anidación y cuidado maternal del Colibrí Esmeralda Hondureño (Amazilia luciae) en el Valle de Agalta, Honduras. Ornitología Neotropical 27:237-46.

Rodríguez, F., J. L. Larkin, S. Y. Cruz, T. M. Mejía, L. F. Ferrufino, and J. Townsend. 2015. Evaluación de biodiversidad y ecosistema en el Valle de Agalta para la protección del Colibri Esmeralda (Amazilia luciae). INVESTH-MCA Honduras, Tegucigalpa, Honduras.

Rodríguez-Flores, C., and S. Wethington. 2017. Exploring the relationship between hummingbird detectability and flower availability. Page 7 in S. M. Wethington and M. Arizmendi, editors. Hummingbirds in a changing world: Why hummingbird conservation matters! VI Partners in Flight International Conference. San José, Costa Rica.

Royle, J. A. 2004a. Generalized estimators of avian abundance from count survey data. Animal Biodiversity and Conservation 27:375-386.

Royle, J. A. 2004b. $N$-Mixture models for estimating population size from spatially replicated counts. Biometrics 60:108-115. http://dx.doi.org/10.1111/j.0006-341X.2004.00142.x

Sánchez-Azofeifa, A., J. Calvo-Alvarado, M. M. Espírito-Santo, G. W. Fernandes, J. S. Powers, and M. Quesada. 2013. Tropical dry forests in the Americas: the Tropi Dry endeavor. Pages 1-16 in A. Sanchez-Azofeifa, J. S. Powers, G. W. Fernandes, and M. Quesada, editors. Tropical dry forests in the Americas: ecology, conservation and management. CRC Press, Boca Raton, Florida, USA.

Segura, L. N., and M. F. Arturi. 2012. La estructura del hábitat influye en la abundancia del cardenal común (Paroaria coronata) en un bosque templado de Argentina. Ornitología Neotropical 23:11-21.

Sillett, S. T., R. B. Chandler, J. A. Royle, M. Kéry, and S. A. Morrison. 2012. Hierarchical distance-sampling models to estimate population size and habitat-specific abundance of an island endemic. Ecological Applications 22:1997-2006. http://dx. doi.org/10.1890/11-1400.1

Skutch, A. F. 1958. Life history of the Violet-headed Hummingbird. Wilson Bulletin 70:5-19.

Snow, D. W., and B. K. Snow. 1986. Feeding ecology of hummingbirds in the Serra do Mar, southeastern Brazil. El Hornero 12:286-296.

Thorn, S., P. House, and D. E. Pérez. 2000. Estudio del Colibrí Esmeralda Hondureño Amazilia luciae y su hábitat. Secretaría de Obras Publicas, Transporte, y Vivienda (SOPTRAVI), Tegucigalpa, Honduras. 
United States Fish and Wildlife Service. 2015. Endangered and threatened wildlife and plants: listing the Honduran Emerald Hummingbird (Amazilia luciae). Federal Register 80:45086-45097.

Volpe, N. L., A. S. Hadley, W. D. Robinson, and M. G. Betts. 2014. Functional connectivity experiments reflect routine movement behavior of a tropical hummingbird species. Ecological Applications 24:2122-2131. http://dx.doi.org/10.1890/13-2168.1

Wolf, L. L. 1964. Nesting of the Fork-tailed Emerald in Oaxaca, Mexico. Condor 66:51-55. http://dx.doi.org/10.2307/1365236

Wolf, L. L., and F. G. Stiles. 1970. Evolution of pair cooperation in a tropical hummingbird. Evolution 24:759-773. http://dx.doi. org/10.1111/j.1558-5646.1970.tb01811.x 
Appendix 1. Spatial autocorrelation test for Honduran Emerald counts during three sampling periods within 2014-2015 in Agalta Valley.

\begin{tabular}{lccccc}
\hline \multicolumn{1}{c}{ Variable } & $\begin{array}{c}\text { Moran's I } \\
\text { observed }\end{array}$ & $\begin{array}{c}\text { Expected } \\
\text { Moran's I }\end{array}$ & $\begin{array}{c}\text { SD } \\
\text { Moran's I }\end{array}$ & $\begin{array}{c}p \\
\text { uncorrected }\end{array}$ & $p$ corrected \\
\hline $\begin{array}{l}\text { Counts } \\
\text { sampling } \\
\text { period 1 }\end{array}$ & 0.0091 & -0.00578 & 0.01489 & 0.3174 & 1 \\
$\begin{array}{l}\text { Counts } \\
\text { sampling } \\
\text { period 2 }\end{array}$ & -0.00595 & -0.00578 & 0.01489 & 0.99 & 1 \\
$\begin{array}{l}\text { Counts } \\
\text { sampling } \\
\text { period 3 }\end{array}$ & -0.01733 & -0.00578 & 0.01461 & 0.4292 & 1 \\
\hline
\end{tabular}


Appendix 2. Complete AICc results for Honduran Emerald detection models for all sampling periods in Agalta Valley during 2014-2015. In sampling period one, both observers conducted the count together for calibration purposes.

\begin{tabular}{|c|c|c|c|c|c|c|}
\hline Sampling Period & $\mathrm{K}^{\dagger}$ & $\mathrm{AICc}$ & $\Delta \mathrm{AICc}$ & $\mathrm{AICc} \mathrm{Wt}^{\ddagger}$ & $\begin{array}{c}\text { Cumulative } \\
\mathrm{Wt}^{\ddagger}\end{array}$ & $\mathrm{LL}^{\S}$ \\
\hline \multicolumn{7}{|l|}{ September-December } \\
\hline$p$ (Julian date $)$ & 3 & 355.33 & 0.00 & 0.69 & 0.69 & -174.59 \\
\hline$p\left(\right.$ Julian date $\left.{ }^{\mid}\right)$ & 4 & 357.27 & 1.94 & 0.26 & 0.95 & -174.52 \\
\hline$p\left(\right.$ Vegetation density $\left.{ }^{\prime}\right)$ & 4 & 362.34 & 7.01 & 0.02 & 0.97 & -177.05 \\
\hline$p()$. & 2 & 362.59 & 7.26 & 0.02 & 0.99 & -179.26 \\
\hline$p$ (Vegetation density) & 3 & 364.48 & 9.15 & 0.01 & 1.00 & -179.17 \\
\hline \multicolumn{7}{|l|}{ March-April } \\
\hline$p$ (Julian date $\left.{ }^{\prime}\right)$ & 4 & 459.72 & 0.00 & 0.85 & 0.85 & -225.74 \\
\hline$p$ (Julian date) & 3 & 463.14 & 3.42 & 0.15 & 1.00 & -228.50 \\
\hline$p()$. & 2 & 476.50 & 16.77 & 0.00 & 1.00 & -236.21 \\
\hline$p$ (Observer) & 3 & 477.55 & 17.83 & 0.00 & 1.00 & -235.71 \\
\hline$p$ (Vegetation density) & 3 & 478.38 & 18.65 & 0.00 & 1.00 & -236.12 \\
\hline$p\left(\right.$ Vegetation density $\left.{ }^{\prime}\right)$ & 4 & 480.21 & 20.49 & 0.00 & 1.00 & -235.99 \\
\hline \multicolumn{7}{|l|}{ June-July } \\
\hline$p$ (Julian date $)$ & 3 & 264.25 & 0.00 & 0.29 & 0.29 & -129.05 \\
\hline$p\left(\right.$ Vegetation density $\left.{ }^{\prime}\right)$ & 4 & 264.61 & 0.36 & 0.24 & 0.54 & -128.19 \\
\hline$p()$. & 2 & 265.29 & 1.04 & 0.17 & 0.71 & -130.61 \\
\hline$p$ (Vegetation density) & 3 & 265.98 & 1.74 & 0.12 & 0.83 & -129.92 \\
\hline$p$ (Julian date $\left.{ }^{\prime}\right)$ & 4 & 266.29 & 2.04 & 0.11 & 0.94 & -129.03 \\
\hline$p$ (Observer) & 3 & 267.36 & 3.11 & 0.06 & 1.00 & -130.61 \\
\hline
\end{tabular}

\footnotetext{
$\dagger$ Number of parameters

$¥$ Weight

$\S \log$-likelihood

| Variable with quadratic term
} 
Appendix 3. Complete AICc results for Honduran Emerald abundance models for two sampling periods in Agalta Valley during 2014-2015.

\begin{tabular}{|c|c|c|c|c|c|c|}
\hline Sampling period & $\mathrm{K}^{\dagger}$ & $\mathrm{AICc}$ & $\Delta \mathrm{AICc}$ & $\begin{array}{l}\mathrm{AICc} \\
\mathrm{Wt}^{\star}\end{array}$ & $\begin{array}{c}\text { Cumulative } \\
\mathrm{Wt}^{\ddagger}\end{array}$ & $\mathrm{LL}^{\S}$ \\
\hline \multicolumn{7}{|l|}{ September-December } \\
\hline $\begin{array}{l}p(\text { Julian date }) \quad \lambda(\text { Shrub strata } \\
\text { density') }\end{array}$ & 5 & 348.70 & 0.00 & 0.64 & 0.64 & -169.17 \\
\hline$p($ Julian date $) \lambda($ Shrub strata density $)$ & 4 & 353.36 & 4.67 & 0.06 & 0.70 & -172.56 \\
\hline$p($ Julian date $) \lambda\left(\right.$ Stems under $\left.3 \mathrm{~cm}^{\prime}\right)$ & 5 & 354.81 & 6.11 & 0.03 & 0.73 & -172.23 \\
\hline$p($ Julian date $) \lambda($ Stems under $3 \mathrm{~cm})$ & 4 & 355.22 & 6.52 & 0.02 & 0.75 & -173.49 \\
\hline$p($ Julian date $) \lambda()$. & 3 & 355.33 & 6.63 & 0.02 & 0.77 & -174.59 \\
\hline $\begin{array}{l}p(\text { Julian date }) \lambda(\text { Eugenia } \\
\text { hondurensis })\end{array}$ & 5 & 355.41 & 6.72 & 0.02 & 0.80 & -172.53 \\
\hline $\begin{array}{l}p(\text { Julian date }) \lambda(\text { Pilosocereus } \\
\text { leucocephalus })\end{array}$ & 4 & 355.48 & 6.78 & 0.02 & 0.82 & -173.62 \\
\hline $\begin{array}{l}p(\text { Julian date }) \lambda(\text { Eugenia } \\
\text { hondurensis })\end{array}$ & 4 & 356.01 & 7.32 & 0.02 & 0.83 & -173.89 \\
\hline $\begin{array}{l}p(\text { Julian date }) \lambda(\text { Cacti structural } \\
\text { diversity })\end{array}$ & 4 & 356.51 & 7.81 & 0.01 & 0.85 & -174.14 \\
\hline $\begin{array}{l}p(\text { Julian date }) \lambda(\text { Erythroxylum } \\
\text { areolatum })\end{array}$ & 4 & 356.60 & 7.91 & 0.01 & 0.86 & -174.18 \\
\hline$p($ Julian date $) \lambda($ Casearia nitida $)$ & 4 & 356.64 & 7.94 & 0.01 & 0.87 & -174.20 \\
\hline$p($ Julian date $) \lambda($ Epiphyte tree count $)$ & 4 & 356.79 & 8.09 & 0.01 & 0.88 & -174.28 \\
\hline$p($ Julian date $) \lambda($ Patch size $)$ & 4 & 357.00 & 8.31 & 0.01 & 0.89 & -174.38 \\
\hline $\begin{array}{l}p(\text { Julian date }) \lambda(\text { Opuntia } \\
\text { hondurensis })\end{array}$ & 4 & 357.06 & 8.36 & 0.01 & 0.90 & -174.41 \\
\hline
\end{tabular}




\begin{tabular}{|c|c|c|c|c|c|c|}
\hline$p$ (Julian date) $\lambda$ (Vegetation density) & 4 & 357.21 & 8.51 & 0.01 & 0.91 & -174.49 \\
\hline$p($ Julian date) $\lambda($ Species richness $)$ & 4 & 357.25 & 8.55 & 0.01 & 0.92 & -174.51 \\
\hline $\begin{array}{l}p(\text { Julian date }) \lambda(\text { Cacti structural } \\
\text { diversityl) }\end{array}$ & 5 & 357.33 & 8.63 & 0.01 & 0.93 & -173.48 \\
\hline$p$ (Julian date) $\lambda($ Acacia picachensis $)$ & 4 & 357.35 & 8.65 & 0.01 & 0.94 & -174.55 \\
\hline$p($ Julian date $) \lambda(\mathrm{HCI})$ & 4 & 357.37 & 8.67 & 0.01 & 0.95 & -174.56 \\
\hline $\begin{array}{l}p(\text { Julian date }) \lambda(\text { Opuntia } \\
\text { hondurensis })\end{array}$ & 5 & 357.42 & 8.72 & 0.01 & 0.95 & -173.53 \\
\hline $\begin{array}{l}p(\text { Julian date }) \lambda(\text { Pilosocereus } \\
\text { leucocephalus })\end{array}$ & 5 & 357.45 & 8.75 & 0.01 & 0.96 & -173.55 \\
\hline$p($ Julian date $) \lambda(\mathrm{HCI})$ & 5 & 357.90 & 9.21 & 0.01 & 0.97 & -173.77 \\
\hline$p($ Julian date $) \lambda($ Epiphyte tree count $)$ & 5 & 358.10 & 9.40 & 0.01 & 0.97 & -173.87 \\
\hline$p($ Julian date $) \lambda($ Casearia nitidal $)$ & 5 & 358.25 & 9.55 & 0.01 & 0.98 & -173.95 \\
\hline$p($ Julian date $) \lambda($ Patch size $)$ & 5 & 358.31 & 9.61 & 0.01 & 0.98 & -173.98 \\
\hline$p$ (Julian date) $\lambda$ (Vegetation density') & 5 & 358.40 & 9.70 & 0.00 & 0.99 & -174.02 \\
\hline $\begin{array}{l}p(\text { Julian date }) \lambda(\text { Erythroxylum } \\
\text { areolatum })\end{array}$ & 5 & 358.57 & 9.88 & 0.00 & 0.99 & -174.11 \\
\hline$p($ Julian date $) \lambda($ Species richness $)$ & 5 & 359.36 & 10.67 & 0.00 & 1.00 & -174.50 \\
\hline$p($ Julian date $) \lambda\left(\right.$ Acacia picachensis $\left.{ }^{\prime}\right)$ & 5 & 359.45 & 10.76 & 0.00 & 1.00 & -174.55 \\
\hline$p(.) \lambda()$. & 2 & 362.59 & 13.90 & 0.00 & 1.00 & -179.26 \\
\hline \multicolumn{7}{|l|}{ March-April } \\
\hline $\begin{array}{l}p(\text { Julian date }) \lambda(\text { Cacti structural } \\
\text { diversity })\end{array}$ & 5 & 452.75 & 0.00 & 0.47 & 0.47 & -221.20 \\
\hline $\begin{array}{l}p(\text { Julian date } \lambda(\text { Cacti structural } \\
\text { diversityl) }\end{array}$ & 6 & 454.87 & 2.11 & 0.16 & 0.63 & -221.18 \\
\hline
\end{tabular}




\begin{tabular}{|c|c|c|c|c|c|c|}
\hline $\begin{array}{l}p \text { (Julian date) } \lambda \text { (Pilosocereus } \\
\text { leucocephalus') }\end{array}$ & 6 & 456.87 & 4.12 & 0.06 & 0.69 & -222.18 \\
\hline$p($ Julian date $) \lambda($ Epiphyte tree count $)$ & 6 & 457.02 & 4.27 & 0.06 & 0.74 & -222.26 \\
\hline$p$ (Julian date) $\lambda($ (Patch size $)$ & 6 & 457.66 & 4.91 & 0.04 & 0.78 & -222.58 \\
\hline $\begin{array}{l}p(\text { Julian date }) \lambda(\text { Opuntia } \\
\text { hondurensis })\end{array}$ & 6 & 458.01 & 5.26 & 0.03 & 0.82 & -222.75 \\
\hline$p($ Julian date $) \lambda(\mathrm{HCI})$ & 6 & 458.32 & 5.56 & 0.03 & 0.85 & -222.91 \\
\hline$p($ Julian date) $\lambda($ Epiphyte tree count $)$ & 5 & 459.50 & 6.75 & 0.02 & 0.86 & -224.57 \\
\hline$p($ Julian date $) \lambda()$. & 4 & 459.72 & 6.97 & 0.01 & 0.88 & -225.74 \\
\hline$p($ Julian date $) \lambda($ Patch size $)$ & 5 & 460.00 & 7.25 & 0.01 & 0.89 & -224.82 \\
\hline$p($ Julian date $) \lambda($ Casearia nitida $)$ & 5 & 460.48 & 7.73 & 0.01 & 0.90 & -225.06 \\
\hline$p($ Julian date $) \lambda($ Stems under $3 \mathrm{~cm})$ & 5 & 460.55 & 7.79 & 0.01 & 0.91 & -225.09 \\
\hline$p($ Julian date) $\lambda($ Species richness $)$ & 5 & 460.79 & 8.04 & 0.01 & 0.92 & -225.22 \\
\hline$p$ (Julian date) $\lambda$ (Species richness $)$ & 5 & 460.88 & 8.13 & 0.01 & 0.93 & -224.19 \\
\hline$p$ (Julian date) $\lambda$ (Vegetation density) & 5 & 460.90 & 8.14 & 0.01 & 0.93 & -225.27 \\
\hline $\begin{array}{l}p(\text { Julian date) } \lambda \text { (Erythroxylum } \\
\text { areolatum })\end{array}$ & 5 & 461.33 & 8.57 & 0.01 & 0.94 & -225.48 \\
\hline $\begin{array}{l}p(\text { Julian date }) \lambda(\text { Pilosocereus } \\
\text { leucocephalus })\end{array}$ & 5 & 461.39 & 8.64 & 0.01 & 0.95 & -225.52 \\
\hline$p$ (Julian date) $\lambda$ (Shrub strata density) & 5 & 461.52 & 8.77 & 0.01 & 0.95 & -225.58 \\
\hline$p($ Julian date $) \lambda(\mathrm{HCI})$ & 5 & 461.52 & 8.77 & 0.01 & 0.96 & -225.58 \\
\hline $\begin{array}{l}p(\text { Julian date }) \lambda(\text { Eugenia } \\
\text { hondurensis })\end{array}$ & 5 & 461.52 & 8.78 & 0.01 & 0.96 & -225.58 \\
\hline$p$ (Julian date $) \lambda($ Shrub strata density $)$ & 6 & 461.57 & 8.82 & 0.01 & 0.97 & -224.53 \\
\hline
\end{tabular}




\begin{tabular}{|c|c|c|c|c|c|c|}
\hline $\begin{array}{l}p(\text { Julian date }) \lambda(\text { Opuntia } \\
\text { hondurensis })\end{array}$ & 5 & 461.74 & 8.98 & 0.01 & 0.97 & -225.69 \\
\hline$p$ (Julian date) $\lambda($ Acacia picachensis $)$ & 5 & 461.83 & 9.08 & 0.00 & 0.98 & -225.74 \\
\hline$p$ (Julian date) $\lambda($ Acacia picachensis $\mid)$ & 6 & 461.91 & 9.16 & 0.00 & 0.98 & -224.70 \\
\hline$p($ Julian date $) \lambda\left(\right.$ Stems under $\left.3 \mathrm{~cm}^{l}\right)$ & 6 & 461.94 & 9.19 & 0.00 & 0.99 & -224.72 \\
\hline$p($ Julian date $) \lambda($ Casearia nitidal $)$ & 6 & 462.50 & 9.75 & 0.00 & 0.99 & -225.00 \\
\hline$p($ Julian date $) \lambda($ Vegetation density $)$ & 6 & 463.03 & 10.27 & 0.00 & 1.00 & -225.26 \\
\hline $\begin{array}{l}p(\text { Julian date }) \lambda(\text { Erythroxylum } \\
\text { areolatum })\end{array}$ & 6 & 463.04 & 10.29 & 0.00 & 1.00 & -225.27 \\
\hline $\begin{array}{l}p(\text { Julian date }) \lambda(\text { Eugenia } \\
\text { hondurensis })\end{array}$ & 6 & 463.61 & 10.86 & 0.00 & 1.00 & -225.55 \\
\hline$p(.) \lambda()$. & 2 & 476.50 & 23.75 & 0.00 & 1.00 & -236.21 \\
\hline
\end{tabular}

${ }^{\dagger}$ Number of parameters

$\$$ Weight

$\S$ log-likelihood

| Variable with quadratic term 